DOI: $10.6060 / \mathrm{mhc} 160109 \mathrm{~m}$

\title{
Unsymmetrically Substituted Phthalocyanine Carboxylic Acids
}

\author{
Sergey G. Makarov, ${ }_{1}^{\mathrm{a}, \mathrm{b} @ 1}$ Alexander S. Kazarin, ${ }_{1}^{\mathrm{a}, \mathrm{b}}$ Olga N. Suvorova, ${ }_{1}^{\mathrm{a}, \mathrm{d}}$ \\ Galina S. Zabrodina, ${ }^{a}$ Mikhail A. Lopatin, ${ }^{a}$ Olga V. Kuznetsova, ${ }^{a}$ Sergey Yu. Ketkov, ${ }^{a}{ }^{\mathrm{a} b}$ \\ and Dieter Wöhrle $@ 2$
}

${ }^{\mathrm{a}}$ G.A. Razuvaev Institute of Organometallic Chemistry of RAS, 603950 Nizhny Novgorod, Russia

${ }^{\mathrm{b}}$ N.I. Lobachevsky State University of Nizhny Novgorod, 603950 Nizhny Novgorod, Russia

'Universität Bremen, Institut für Organische und Makromolekulare Chemie, 28334 Bremen, Germany

'Intelpharm Group of Companies, 603000 Nizhny Novgorod, Russia

${ }^{\circledR 1}$ Corresponding author E-mail: makarsg@mail.ru

${ }^{\circledR 2}$ Corresponding authorE-mail:woehrle@uni-bremen.de

\begin{abstract}
New unsymmetrically substituted phthalocyanine carboxylic acids were synthesized by mixed cyclotetramerization of substituted phthalonitriles. The UV-vis absorption and fluorescence spectra and quantum yields of fluorescence were studied in comparison to symmetrically substituted analogues. The distribution of phthalocyanine carboxylic acids on the surface of titanium dioxide was studied by UV-vis absorption spectroscopy.
\end{abstract}

Keywords: Unsymmetrically substituted phthalocyanines, photophysical properties, dye-sensitized solar cells.

\section{Несимметрично замещенные фталоцианинкарбоновые кислоты}

\author{
С. Г. Макаров, ${ }^{a, b @ 1}$ A. С. Казарин, ${ }^{a, b}$ О. Н. Суворова, ${ }^{a, d}$ Г. С. Забродина, ${ }^{a}$ \\ M. А. Лопатин, ${ }^{a}$ О. В. Кузнецова, ${ }^{a}$ C. Ю. Кетков, ${ }^{\text {a,b }}$ А. Вёрле $@ 2$ \\ а Институт металлоорганической химии им. Г.А. Разуваева РАН, 603950 Нижний Новгород, Россия \\ ${ }^{\mathrm{b}}$ Нижегородский государственный университет им. Н.И. Лобачевского, 603950 Нижний Новгород, Россия \\ 'Бременский университет, Институт органической и макромолекулярной химии, 28334 Бремен, Германия \\ dГруппа компаний Интелфарм, 603000 Нижний Новгород, Россия \\ @1E-mail:makarsg@mail.ru \\ ${ }^{\circledR 2}$ E-mail: woehrle@uni-bremen.de
}

\begin{abstract}
Синтезированы новые несимметрично замещченные фталоцианинкарбоновые кислоты методом смешанной цииклотетрамеризации замещенных фталонитрилов. Изучены электронные спектры поглощения и флуоресценции в УФ и видимой области и квантовые выходы флуоресценции в сравнении с симметрично замещенныли аналогами. Методом электронной спектроскопии поглощения изучен характер распределения фталоцианинкарбоновых кислот на поверхности диоксида титана.
\end{abstract}

Ключевые слова: Несимметрично замещенные фталоцианины, фотофизические свойства, фотоэлектрохимические солнечные элементы. 


\section{Introduction}

In recent years, phthalocyanines (Pcs) have attracted significant attention as photosensitizers in dye-sensitized solar cells (DSSCs) $)^{[1-8]}$ due to their high photochemical/ electrochemical stability and intense absorption in the rednear infrared region. In DSSC, photosensitizer is usually attached to the titanium dioxide surface via one or two carboxylic groups which have to be $\pi$-conjugated with the chromophore for efficient photoinduced electron transfer to $\mathrm{TiO}_{2}$. The highest power conversion efficiency (PCE) of $13 \%$ of a DSSC was obtained for an unsymmetrical porphyrin derivative as photosensitizer. ${ }^{[9]}$ The advantage of phthalocyanines is their strong absorption in the red-near infrared (NIR) region. But they have very little absorption in the middle of the visible region, and highest PCE of Pcbased DSSC is only $6.4 \% .^{[6]}$ Phthalocyanine-based DSSCs can be interesting as components of "smart windows" mostly transparent for visible light, or in combination with other photosensitizers ${ }^{[8-12]}$ to improve red-NIR response of the cells. First phthalocyanines for DSSCs were prepared in the group of Wöhrle in $1999^{[13]}$ but the efficiency did not exceed $1 \%$. Later, different structural modifications of the phthalocyanine molecule were made to improve the efficiency of DSSCs, such as:

- Modification of the central metal ion and extraligands. Mainly $\mathrm{Zn}^{\mathrm{II}}, \mathrm{Ru}^{\mathrm{II}}, \mathrm{Si}^{\mathrm{IV}}$, $\mathrm{Ti}^{\mathrm{IV}}$ phthalocyanines were studied as photosensitizers. In most cases $\mathrm{Zn}^{\mathrm{II}}$ showed the highest efficiency. The influence of the central metal ion is discussed in detail by Torres et al. ${ }^{\left[{ }^{[8]}\right.}$

- Modification of the linker between the carboxylic group and the phthalocyanine core. It was shown ${ }^{[1-8]}$ that rigid conjugated linkers are essential for efficient charge transfer from the excited $\mathrm{Pc}$ molecule to $\mathrm{TiO}_{2}$. The highest efficiencies were achieved when one carboxylic group was connected directly or via an ethynyl linker to one of the benzene rings of a phthalocyanine. ${ }^{[1-8]}$

- Modification of substituents at other benzene rings. Unsymmetrically substituted phthalocyanines of the ABBB type containing one or two carboxylic groups at one benzene ring of $\mathrm{A}$ are preferable. The main disadvantage of phthalocyanines as photosensitizers is their strong aggregation on the surface which leads to excited states quenching and decreased charge separation efficiency. The PCE of $5.9-6.4 \%$ was achieved with the help of very bulky substituents at three benzene rings B like 2,6-diphenylphenoxy-, 2,6-diisopropylphenoxy-, 4-methoxy-2,6-diphenylphenoxy-, 2,6-dibutoxyphenoxy-, etc., whereas "traditional" tert-butyl groups were not bulky enough to suppress aggregation (the resulting PCE was only $3.5 \%) .{ }^{[8]}$ The side effect of using too bulky substituents is the reduced light absorption due to decreased dye adsorption density, together with lower yields of the Pcs and expensive starting materials. Therefore it is important to find "minimal" substituents, just enough to suppress the Pc aggregation on the surface. One possible way is to use six smaller substituents, other possibility is to use three bulky substituents instead of six at the three benzene rings $\mathrm{B}$.

Based on the before mentioned results described in the literature it was the aim in the present study, to prepare structurally optimized unsymmetrically substituted zinc(II) phtha- locyanines with six 2,6-dimethylphenoxy substituents and with three 2,6-di-tert-butyl-4-methylphenoxy substituents at three benzene rings B. The fourth benzene ring A contains a directly connected carboxylic group. Their fluorescence properties and aggregation behaviour on $\mathrm{TiO}_{2}$ surface was studied.

\section{Experimental}

\section{Materials}

Methyl3,4-dicyanobenzoate 1,4,5-bis(2,6-dimethylphenoxy)phthalonitrile 2, 4-(2,6-di-tert-butyl-4-methylphenoxy)phthalonitrile 5, zinc 2,3,9,10,16,17,23,24-octakis-(2,6-dimethylphenoxy)phthalocyanine $\mathbf{8}$ and zinc 2,9,16,23-tetrakis-(2,6-di-tert-butyl4-methylphenoxy)phthalocyanine 9 were prepared as previously described..$^{[7,14-16]}$ Analytical reagent grade (Sigma-Aldrich) sodium hypochlorite solution (14\% active chlorine), nickel(II) chloride hexahydrate, 2,2'-bipyridyl, 1,8-diazabicyclo[5.4.0]undec-7-ene (DBU) and titanium dioxide nanoparticles (Degussa P25 grade, $21 \mathrm{~nm}$ primary particle size) were used as purchased. Zinc acetate dihydrate (analytical reagent grade, Sigma-Aldrich) was dried under vacuum at $120^{\circ} \mathrm{C}$ for $4 \mathrm{~h}$. The solvents used for the preparations (Sigma-Aldrich, VWR, reagent grade) were dried, distilled and stored under dry conditions. All syntheses were carried out under dry high purity nitrogen. Silica gel $60(40-63 \mu \mathrm{m}$; VWR) was used for chromatographic separations.

\section{Measurements}

${ }^{1} \mathrm{H}$ NMR spectra were recorded using a Bruker Avance DPX-200 (200 MHz) spectrometer, electrospray ionisation (ESI) MS spectra using a Bruker Esquire LC mass-spectrometer and IR spectra with a FSM 1201 spectrometer. The UV-vis absorption spectra were obtained at room temperature using a Perkin-Elmer Lambda 25 spectrophotometer. The adsorption of phthalocyanine carboxylic acids on $\mathrm{TiO}_{2}$ was carried out as previously described, ${ }^{[1]}$ by immersion of $\mathrm{TiO}_{2}$ powder in $0.1 \mathrm{mM}$ Pc solution for $4 \mathrm{~h}$ followed by centrifugation and washing the precipitate with THF. The UV-vis spectra on the surface of titanium dioxide were recorded in $\mathrm{KBr}$ pellets prepared in the same way as for IR spectroscopy. The final spectra were obtained by substracting the spectrum of pure $\mathrm{TiO}_{2}$ in $\mathrm{KBr}$ which is essentially a spectrum of light dispersion by $\mathrm{TiO}_{2}$ particles. The fluorescence spectra were obtained at room temperature using Perkin-Elmer LS55 with a standard $150 \mathrm{~W} 50 \mathrm{~Hz}$ xenon flash lamp as a source. For all spectra quartz cuvettes $1 \times 1 \mathrm{~cm}$ were used. The wavelength employed for the excitation was $610 \mathrm{~nm}$, the slit width $2.5 \mathrm{~nm}$ for excitation and for emission. The optical density of the main Q-band maximum was in the range of 0.2 to 0.3 to minimize reabsorption. The compound $\mathbf{8}$ with $\Phi_{\mathrm{F}}=0.28$ measured earlier ${ }^{[15]}$ with higher precision was used as a reference for fluorescence quantum yield estimations.

\section{Syntheses}

Zinc(II) 2-pentoxycarbonyl-9,10,16,17,23,24-hexakis(2,6dimethylphenoxy)phthalocyanine (3). A mixture of 4,5-bis(2,6dimethylphenoxy)phthalonitrile (0.74 g, $2 \mathrm{mmol})$ 2, methyl 3,4-dicyanobenzoate 1 (93 mg, $0.5 \mathrm{mmol})$, zinc acetate $(0.22 \mathrm{~g}, 1.2$ $\mathrm{mmol}$ ) and 1,8-diazabicyclo[5.4.0]undec-7-ene (DBU) $(0.5 \mathrm{~mL})$ in $n$-pentanol $(5 \mathrm{~mL})$ was heated under reflux for 6 hours. After cooling the mixture was diluted with methanol $(20 \mathrm{~mL})$, the precipitate was collected by centrifugation, washed with methanol, dried under vacuum and dissolved in toluene. The resulting solu- 
tion was separated by column chromatography on silica gel ( $60 \AA$, 40-63 $\mu \mathrm{m}$ ) eluting with toluene-diethyl ether gradually increasing diethyl ether content from 0 to 6 vol. \%. The second green fraction was collected. After solvent evaporation and reprecipitation from toluene with hexane, the precipitate was dried under vacuum at $60{ }^{\circ} \mathrm{C}$. Dark green powder. Yield $130 \mathrm{mg}(18 \%) . \mathrm{m} / \mathrm{z}\left(\mathrm{ESI}, \mathrm{CH}_{2} \mathrm{Cl}_{2} /\right.$ DMF 1:10): $1411\left[(\mathrm{M}+\mathrm{H})^{+}\right], 1433\left[(\mathrm{M}+\mathrm{Na})^{+}\right], 1449\left[(\mathrm{M}+\mathrm{K})^{+}\right]$, $1445\left[(\mathrm{M}+\mathrm{Cl})^{-}\right] .{ }^{1} \mathrm{H}$ NMR $(200 \mathrm{MHz},[\mathrm{D} 6] \mathrm{DMSO}+0.01 \mathrm{M} \mathrm{KCN})$ $\delta_{\mathrm{H}}$ ppm: $9.55 \mathrm{~s}(1 \mathrm{H}), 9.15 \mathrm{~d}(8.1 \mathrm{~Hz}, 1 \mathrm{H}), 8.59(\mathrm{~d} 8.1 \mathrm{~Hz}, 1 \mathrm{H}), 8.16$ $\mathrm{s}(1 \mathrm{H}), 8.14 \mathrm{~s}(1 \mathrm{H}), 7.90 \mathrm{br} \mathrm{s}(2 \mathrm{H}), 7.85 \mathrm{br} \mathrm{s}(2 \mathrm{H}), 7.30-7.67 \mathrm{br} \mathrm{m}$ $(18 \mathrm{H}), 4.43 \mathrm{t}(6.6 \mathrm{~Hz}, 2 \mathrm{H}), 2.28-2.44 \mathrm{br} \mathrm{m}(36 \mathrm{H}), 1.88 \mathrm{br} \mathrm{m}(2 \mathrm{H})$, $1.42-1.59$ br m $(4 \mathrm{H}), 1.00$ br t $(6.8 \mathrm{~Hz}, 3 \mathrm{H})$. IR (mineral oil) $v_{\max }$ $\mathrm{cm}^{-1}: 1720,1698 \mathrm{sh}$.

Zinc(II) 2-carboxy-9,10,16,17,23,24-hexakis(2,6-dimethylphenoxy)phthalocyanine (4). To a solution containing 3 (70 mg, $0.05 \mathrm{mmol})$ in THF $(10 \mathrm{~mL})$ an aqueous $3 \mathrm{M}$ sodium hydroxide solution $(1 \mathrm{~mL})$ was added. The mixture was stirred under reflux for 16 hours. After that, the solution was neutralized, concentrated to a small volume (approx. $2 \mathrm{~mL}$ ), acidified with concentrated hydrochloric acid to $\mathrm{pH} 3$ and diluted with water $(10 \mathrm{~mL})$. The precipitate was collected by centrifugation, washed with water and dried under vacuum at $60{ }^{\circ} \mathrm{C}$. Dark green powder. Yield 61 $\mathrm{mg}(91 \%) . \mathrm{m} / \mathrm{z}$ (ESI, $\mathrm{CH}_{2} \mathrm{Cl}_{2} / \mathrm{DMF}$ 1:10): $1341[\mathrm{M}+\mathrm{H}]^{+}, 1363$ $[\mathrm{M}+\mathrm{Na}]^{+}, 1379[\mathrm{M}+\mathrm{K}]^{+}, 1385[\mathrm{M}-\mathrm{H}+2 \mathrm{Na}]^{+}, 1401[\mathrm{M}-\mathrm{H}+\mathrm{Na}+\mathrm{K}]^{+}$, $1375[\mathrm{M}+\mathrm{Cl}] \cdot{ }^{1} \mathrm{H}$ NMR $(200 \mathrm{MHz},[\mathrm{D} 6] \mathrm{DMSO}+0.01 \mathrm{M} \mathrm{KCN}) \delta_{\mathrm{H}}$ ppm: $9.48 \mathrm{~s}(1 \mathrm{H}), 8.88 \mathrm{~d}(8.1 \mathrm{~Hz}, 1 \mathrm{H}), 8.58 \mathrm{~d}(8.1 \mathrm{~Hz}, 1 \mathrm{H}), 8.15 \mathrm{~s}$ $(1 \mathrm{H}), 8.14 \mathrm{~s}(1 \mathrm{H}), 7.89 \mathrm{~m}(2 \mathrm{H}), 7.85 \mathrm{br} \mathrm{s}(2 \mathrm{H}), 7.34-7.62 \mathrm{~m}(18 \mathrm{H})$, 2.30-2.44 br m (36H). IR (mineral oil) $v_{\max } \mathrm{cm}^{-1}: 1692 \mathrm{br}$.

Phthalocyanines 6 and 7 were prepared by the same procedures as for compounds $\mathbf{3}$ and $\mathbf{4}$, from phthalonitriles $\mathbf{1}$ ( $93 \mathrm{mg}, 0.5 \mathrm{mmol}$ ) and $\mathbf{5}(0.69 \mathrm{~g}, 2 \mathrm{mmol})$.

Zinc(II) 2-pentoxycarbonyl-9, 16,23-tris(2,6-di-tert-butyl-4methylphenoxy)phthalocyanine (mixture of isomers) (6). Dark blue powder. Yield $109 \mathrm{mg}$ (16\%). m/z (ESI, $\mathrm{CH}_{2} \mathrm{Cl}_{2} / \mathrm{DMF}$ 1:10): 1345 $[\mathrm{M}+\mathrm{H}]^{+}, 1367[\mathrm{M}+\mathrm{Na}]^{+}, 1379[\mathrm{M}+\mathrm{Cl}]^{+} .{ }^{1} \mathrm{H}$ NMR $(200 \mathrm{MHz},[\mathrm{D} 6]$ $\mathrm{DMSO}+0.01 \mathrm{M} \mathrm{KCN}) \delta_{\mathrm{H}}$ ppm: 9.73-9.89 br m (1H), 9.12-9.46 br $\mathrm{m}(7 \mathrm{H}), 8.64-8.78$ br $\mathrm{m}(1 \mathrm{H}), 7.96-8.27$ br m $(3 \mathrm{H}), 7.08-7.30$ br m $(6 \mathrm{H}), 4.55$ br t $(6.3 \mathrm{~Hz}, 2 \mathrm{H}), 2.02-2.19$ br s $(9 \mathrm{H}), 1.88-2.02$ br m $(2 \mathrm{H}), 1.46-1.69$ br m $(4 \mathrm{H}), 1.26-1.46$ br m $(54 \mathrm{H}), 1.01$ br t $(7.1 \mathrm{~Hz}$, $3 \mathrm{H})$. IR (mineral oil) $v_{\max } \mathrm{cm}^{-1}: 1721,1696 \mathrm{sh}$.
Zinc(II) 2-carboxy-9,16,23-tris(2,6-di-tert-butyl-4-methylphenoxy)phthalocyanine (mixture of isomers) (7). Dark blue powder. Yield $56 \mathrm{mg}(88 \%) . \mathrm{m} / z$ (ESI, $\left.\mathrm{CH}_{2} \mathrm{Cl}_{2} / \mathrm{DMF} 1: 10\right): 1275$ $[\mathrm{M}+\mathrm{H}]^{+}, 1297[\mathrm{M}+\mathrm{Na}]^{+}, 1313[\mathrm{M}+\mathrm{K}]^{+}, 1319[\mathrm{M}-\mathrm{H}+2 \mathrm{Na}]^{+}, 1335$ $[\mathrm{M}-\mathrm{H}+\mathrm{Na}+\mathrm{K}]^{+}, 1309[\mathrm{M}+\mathrm{Cl}]^{+}, 1331[\mathrm{M}-\mathrm{H}+\mathrm{Na}+\mathrm{Cl}]^{+} .{ }^{1} \mathrm{H} \mathrm{NMR}$ $\left(200 \mathrm{MHz}\right.$, [D6]DMSO + 0.01 M KCN) $\delta_{\mathrm{H}}$ ppm: 9.85 br s $(1 \mathrm{H})$, 9.14-9.55 br m $(7 \mathrm{H}), 8.67-8.78$ br $\mathrm{m}(1 \mathrm{H}), 7.90-8.27$ br $\mathrm{m}(3 \mathrm{H})$, 7.02-7.26 br m (6H), 2.03-2.18 br m (9H), 1.28-1.44 br m (54H). IR (mineral oil) $v_{\max } \mathrm{cm}^{-1}: 1719 \mathrm{br}$.

\section{Results and Discussion}

\section{Synthesis}

The preparation and spectral characterization of new unsymmetrically substituted zinc(II) phthalocyanines with one directly connected carboxylic group are described.

All phthalocyanines were synthesized by mixed cyclotetramerization of the corresponding substituted phthalonitriles. At first 2,6-dimethylphenoxy- and 2,6-di-tert-butyl4-methylphenoxy substituted phthalonitriles $\mathbf{2}$ and $\mathbf{5}$ were obtained using conventional methods based on aromatic nucleophilic substitution. ${ }^{[14,16]}$ The carboxy substituded phthalonitrile 1 was prepared as described previously. ${ }^{[7]}$

Then in a second step unsymmetrically substituted zinc phthalocyanines $\mathbf{3}$ and $\mathbf{6}$ were synthesized in good yields by the statistical mixed cyclotetramerization of the carboxysubstituted phthalonitrile $\mathbf{1}$ and the bulky phenoxy-substituted phthalonitriles $\mathbf{2}$ and $\mathbf{5}$ in the presence of the organic base 1,8-diazabicyclo[5.4.0] undec-7-ene (DBU) and zinc acetate in boiling pentanol (Figures 1 and 2). The obtained statistical mixtures of phthalocyanines was separated by column chromatography on silica gel using gradient elution with a toluene-diethyl ether mixture. The pentyl ester group is used as a "protecting group" necessary for a successful

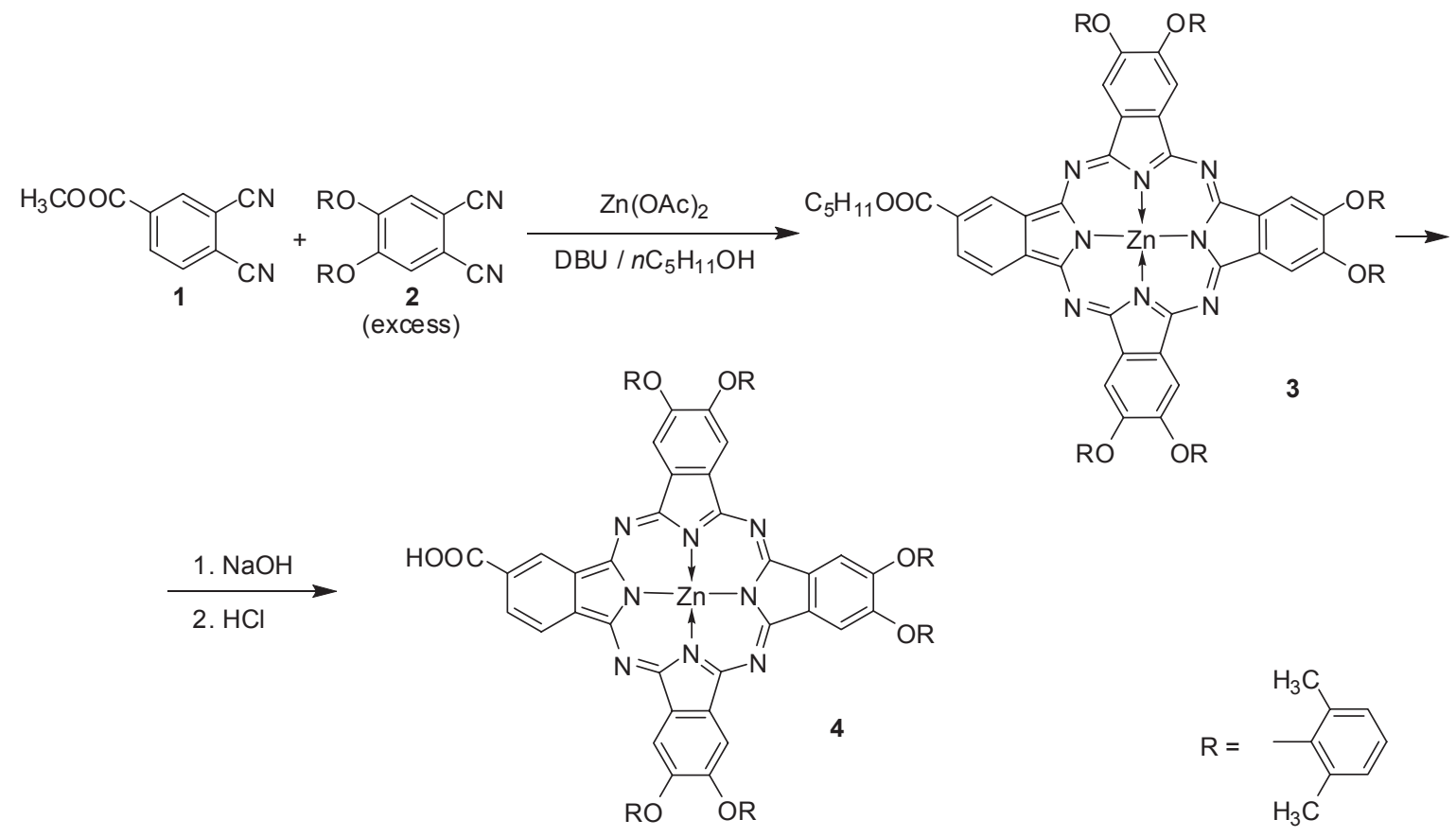

Figure 1. Synthesis of the unsymmetrically substituted phthalocyanines $\mathbf{3}$ and $\mathbf{4}$. 


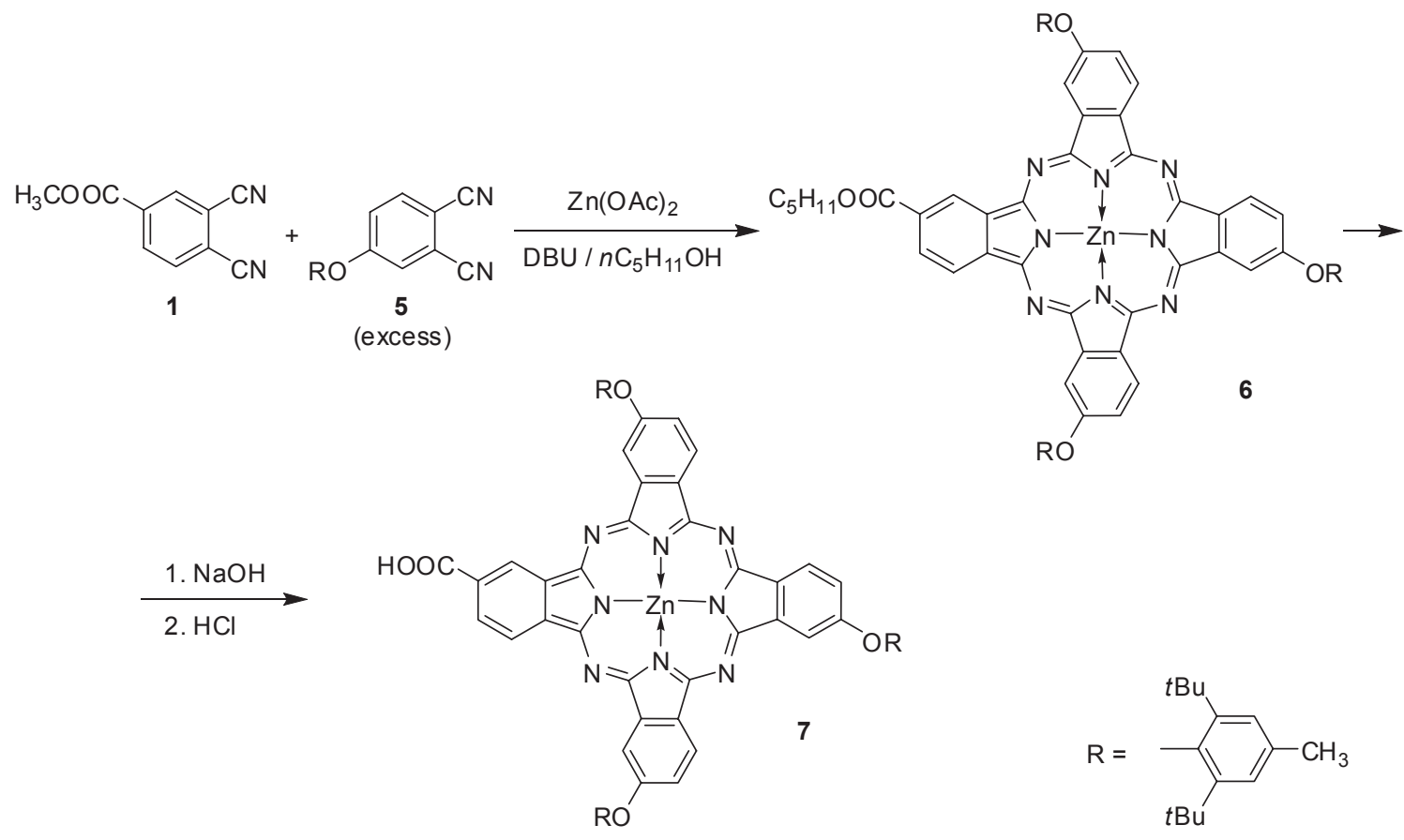

Figure 2. Synthesis of the unsymmetrically substituted phthalocyanines 6 and 7 .

separation of the phthalocyanine mixtures. Unwanted partial cleavage of the ester groups of the compounds $\mathbf{3}$ and $\mathbf{6}$ occurs if lithium or magnesium alkoxide is used as a basic catalyst, and therefore the DBU method ${ }^{[17]}$ is preferable.

In the final step the carboxylic ester groups of $\mathbf{3}$ and $\mathbf{6}$ were cleaved with sodium hydroxide in THF-water mixture to obtain the unsymmetrically substituted zinc phthalocyanine carboxylic acids $\mathbf{4}$ and $\mathbf{7}$ in nearly quantitative yields. All compounds were characterized by ${ }^{1} \mathrm{H}$ NMR, IR and ESI-MS spectra. It is necessary to point out that the compounds 6 and 7 are not single compounds but mixtures of positional isomers; the structural formula show only one of four possible isomers for each compound (same as in the case of symmetrically tetrasubstituted phthalocyanines ${ }^{[18]}$ ).

\section{Absorption and Fluorescence Spectra}

UV-vis absorption and fluorescence spectra were recorded for the unsymmetrical Pcs 3, 4, 6 and 7 (esters and free carboxylic acids) and their symmetrical analogues $\mathbf{8}$ and 9. An example of absorption and fluorescence spectra in tetrahydrofuran is shown in the Figure 3, the main spectral data are compared in the Table 1.

A small splitting of the Q-band is a result of the reduced symmetry. The change of the fluorescence band shape is minimal compared to symmetrical analogues, the Stokes shift is as small as it is usually observed for phthalocyanines (approx. 5-10 $\mathrm{nm}$ or $100-200 \mathrm{~cm}^{-1}$ ). ${ }^{[19]}$ In contrast, the estimated fluorescence quantum yield is significantly reduced compared to symmetrical analogues, both for esters and free carboxylic acids. This could be a result of either selfquenching or intersystem crossing. The measurements of the triplet state quantum yield are in progress to understand the quenching mechanism of the excited singlet state. In the literature, unsymmetrically substituted zinc phthalocyanines

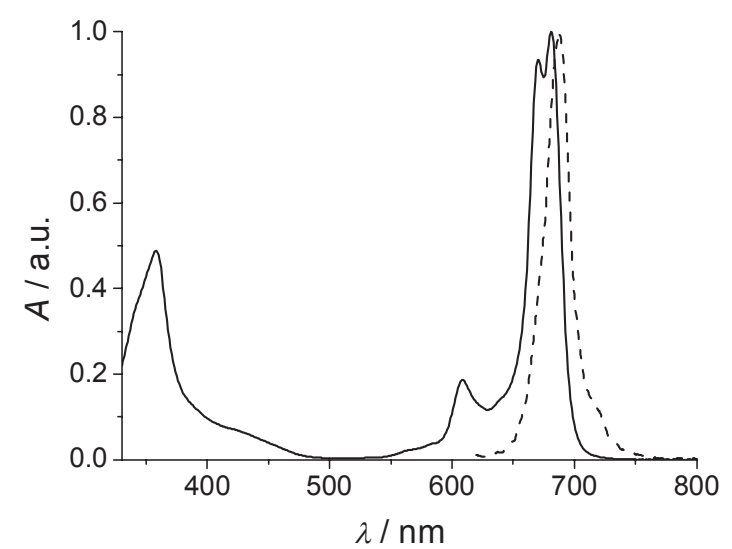

Figure 3. UV-vis absorption (solid line) and emission (dashed line) spectra of $\mathbf{4}$ in THF.

Table 1. Absorption and fluorescence maxima and estimated fluorescence quantum yields of $\mathrm{ZnPcs}$.

\begin{tabular}{cccc}
\hline Phthalocyanine & $\begin{array}{c}\lambda_{\text {maxA }} \text { Q-band } \\
\text { absorption } \\
\text { maximum }\end{array}$ & $\begin{array}{c}\lambda_{\text {maxF }} \text { Q-band } \\
\text { fluorescence } \\
\text { maximum }\end{array}$ & $\begin{array}{c}\text { Fluorescence } \\
\text { quantum yield } \\
\Phi_{\mathrm{F}}\end{array}$ \\
\hline $\mathbf{3}$ & 683 & 689 & 0.14 \\
$\mathbf{4}$ & 681 & 687 & 0.16 \\
$\mathbf{6}$ & 676 & 687 & 0.12 \\
$\mathbf{7}$ & 674 & 685 & 0.14 \\
$\mathbf{8}$ & 674 & 679 & 0.28 \\
$\mathbf{9}$ & 673 & 678 & 0.27 \\
\hline
\end{tabular}

often show reduced quantum yields of the fluorescence whereas the triplet state quantum yields remain relatively high $(0.5-0.6) .{ }^{[19-21]}$ 




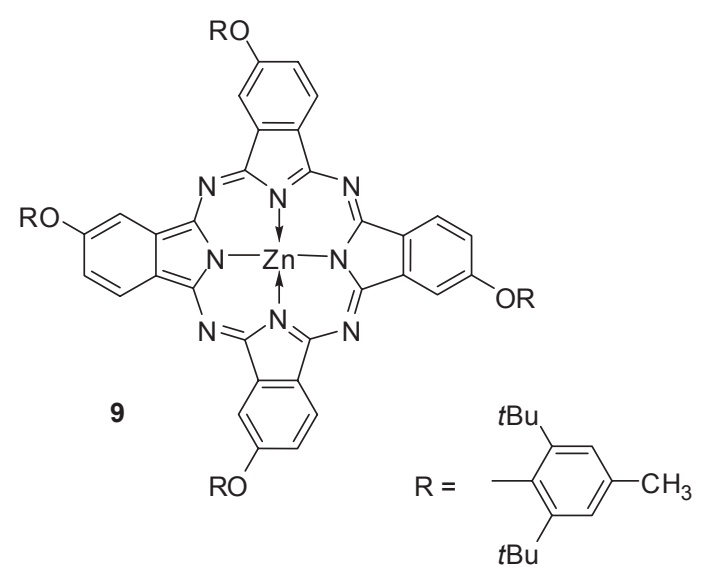

The zinc(II) phthalocyanine carboxylic acids $\mathbf{4}$ and $\mathbf{7}$ were successfully adsorbed on titanium dioxide (Degussa $\mathrm{P} 25$, average particle size $21 \mathrm{~nm}$ ) from THF solution. The $\mathrm{UV}$-vis absorption spectra were recorded in $\mathrm{KBr}$ pellets, and the final spectra were obtained by subtracting the spectrum of titanium dioxide to (partially) eliminate contribution of light scattering by the particles. Although complete subtraction of the scattering was not possible (broad slope at shorter wavelengths) the Q-band quality is enough to compare with the solution spectra.

The UV-vis spectra of the compounds 4 and 7 on the surface of titanium dioxide are shown in the Figure 4A,B. The solution spectra are shown for comparison. The Q-bands are slightly broadened and red-shifted. The broad absorption band at 600-650 nm typical for aggregated $\mathrm{Pcs}^{[22]}$ is present in the spectrum of 7 with relatively low intensity. Such a band is not observed in the UV-vis spectrum of $\mathbf{4}$ which indicates mostly monomolecular distribution of the Pc on the surface. Therefore, relatively small 2,6-dimethylphenoxy groups are bulky enough to efficiently suppress aggregation of a phthalocyanine on the surface whereas a smaller number of much more sterically hindering substituents is less efficient. For comparison, zinc 2-carboxy-9,16,23-tris-tert-butylphthalocyanine (an ABBB phthalocyanine with one carboxy group in the benzene ring of A and one tert-butyl group in each of the three benzene rings $\mathrm{B}$ ) shows even stronger aggregation on $\mathrm{TiO}_{2}$ surface (Figure 4C). ${ }^{[1]}$ Thus, it had been shown that aggregation of zinc phthalocyanines on $\mathrm{TiO}_{2}$ can be efficiently suppressed
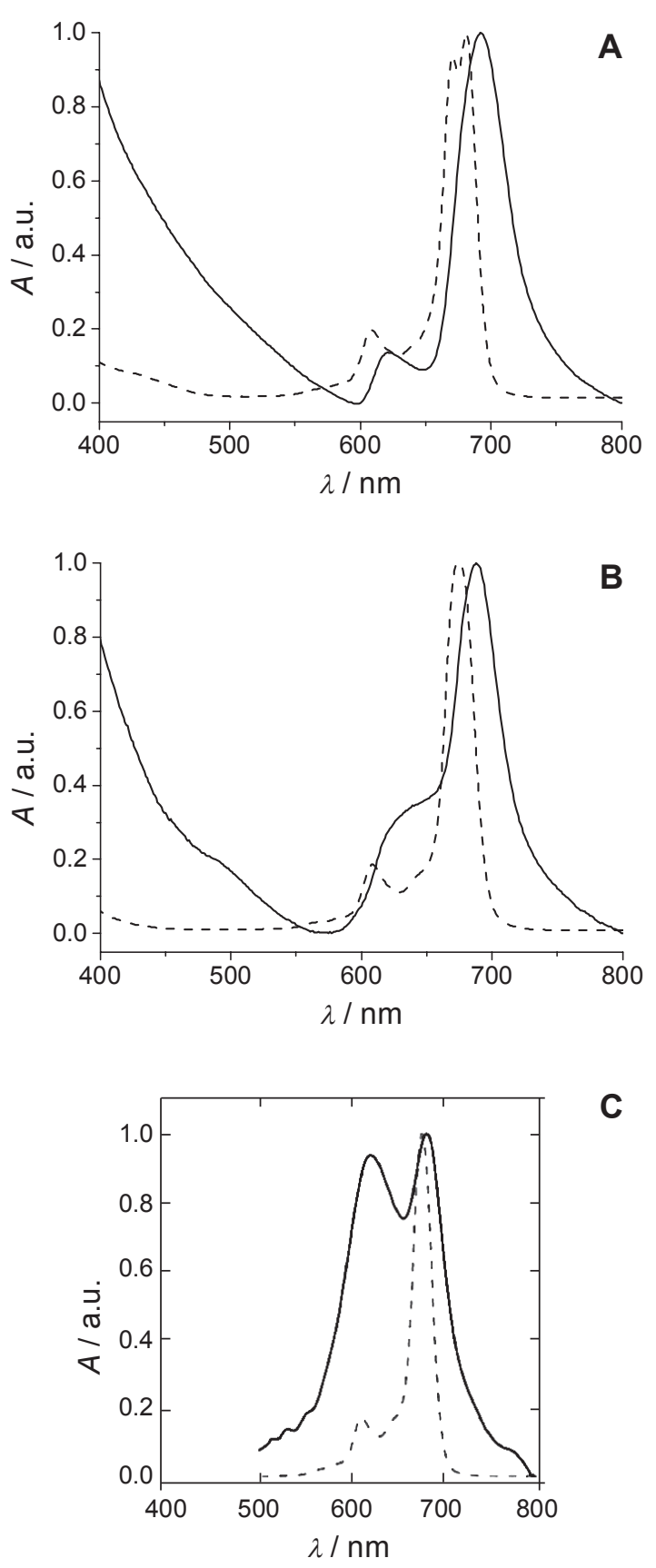

Figure 4. UV-vis absorption spectra of phthalocyanines 4 (A) and 7 (B) on $\mathrm{TiO}_{2}$ (solid) and in THF (dashed). The corresponding spectra of zinc tri-tert-butylphthalocyaninecarboxylic acid $(\mathbf{C})^{[1]}$ are shown for comparison.

by a proper choice of not too bulky substituents which will allow efficient photo-induced electron transfer to $\mathrm{TiO}_{2}$. The photovoltaic performance of $\mathbf{4}$ and $\mathbf{7}$ in DSSC will be examined in the collaboration with another research groups.

\section{Conclusions}

New unsymetrically substituted phthalocyanines of the ABBB type with a single directly attached carboxylic 
groups at the benzene ring A and three or six bulky phenoxy substituents at the benzene rings B were prepared by mixed cyclotetramerization of substituted phthalonitriles.

The changes of UV-vis absorption and fluorescence spectra compared to symmetrically substituted analogues are minimal. The unsymmetrical electronic structure of the prepared phthalocyanines is indicated by significantly reduced fluorescence quantum yield compared to symmetrical analogues as known from the literature. More extended study of photophysical properties is necessary to understand the quenching mechanism of the excited singlet state.

Adsorbed on titanium dioxide, unsymmetrical phthalocyanine carboxylic acids $\mathbf{4}$ and 7 show little or no aggregation as indicated by their UV-vis absorption spectra. This makes them promising as photosensitizers in photocatalysis and dye-sensitized solar cells.

Acknowledgements. Authors thank DAAD and Russian Foundation for Basic Research (projects 14-03-31121 mol a, 14-03-31101 mol_a and 13-03-00542 A) for financial support.

\section{References}

1. Mori S., Nagata M., Nakahata Yu., Yasuta K., Goto R., Kimura M., Taya M. J. Am. Chem. Soc. 2010, 132, 4054-4055.

2. Ragoussi M.-E., Yum J.-H., Chandiran A.K., Ince M., de la Torre G., Grätzel M., Nazeeruddin M.K., Torres T. ChemPhysChem 2014, 15, 1033-1036.

3. Kimura M., Nomoto H., Suzuki H., Ikeuchi T., Matsuzaki H., Murakami T.N., Furube A., Masaki N., Griffith M.J., Mori S. Chem. Eur. J. 2013, 19, 7496-7502.

4. Ince M., Yum J.-H., Kim Yo., Mathew S., Grätzel M., Torres T., Nazeeruddin M.K. J. Phys. Chem. C 2014, 118, 1716617170.

5. Ragoussi M.-E., Cid J.-J., Yum J.-H., de la Torre G., Di Censo D., Grätzel M., Nazeeruddin M.K., Torres T. Angew. Chem. Int. Ed. 2012, 51, 4375-4378.
6. Ikeuchi T., Nomoto H., Masaki N., Griffith M., Mori S., Kimura M. Chem. Commun. 2014, 50, 1941-1943.

7. Pozzi G., Quici S., Raffo M.C., Bignozzi C.A., Caramori S., Orlandi M. J. Phys. Chem. C 2011, 115, 3777-3788.

8. Ragoussi M.-E., Ince M., Torres T. Eur. J. Org. Chem. 2013, 6475-6489.

9. Mathew S., Yella A., Gao P., Humphyr-Baker R., Curchod B.F.E., Ashari-Astani N., Tavernelli I., Rothlisberger U., Nazeeruddin M.K., Grätzel M. Nature Chemistry 2014, 6, 242-247.

10. Yu L., Fan K., Duan T., Chen X., Li R., Peng T. ACS Sustainable Chem. Eng. 2014, 2, 718-725.

11. Margulis G.Y., Lim B., Hardin B.E., Unger E.L. Yum J.-H., Feckl J.M., Fattakhova-Rohlfing D., Bein T., Grätzel M., Sellinger A., McGehee M.D. Phys. Chem. Chem. Phys. 2013, 15, 11306-11312.

12. Baranwal A.K., Fujikawa N., Hayat A., Ogomi Yu., Pandey S.S., Ma T., Hayasee Sh. Appl. Phys. Express 2015, 8, 102301.

13. Nazeeruddin M.K., Humphry-Baker R., Grätzel M., Wöhrle D., Schnurpfeil G., Schneider G., Hirth A., Trombach N. J. Porphyrins Phthalocyanines 1999, 3, 230-237.

14. Makarov S., Litwinski Ch., Ermilov E.A., Suvorova O., Röder B., Wöhrle D. Chem. Eur. J. 2006, 12, 1468-1474.

15. Makarov S., Suvorova O., Litwinski Ch., Ermilov E.A., Röder B., Tsaryova O., Wöhrle D. Eur. J. Inorg. Chem. 2007, 546-552.

16. Brewis M., Clarkson G.J., Humberstone P., Makhseed S., McKeown N.B. Chem. Eur. J. 1998, 4, 1633-1640.

17. Wöhrle D., Schnurpfeil G., Knothe G. Dyes Pigm. 1992, 18, $91-102$.

18. McKeown N.B. The Synthesis of Symmetrical Phthalocyanines. In: The Porphyrin Handbook (Kadish K., Smith K., Guilard R., Eds.). San Diego: Academic Press, 2003, Vol. 15, p. $61-124$.

19. Ishii K., Kobayashi N. The Photophysical Properties of Phthalocyanines and Related Compounds. In: The Porphyrin Handbook (Kadish K., Smith K., Guilard R., Eds.). San Diego: Academic Press, 2003, Vol. 16, p. 1-42.

20. Ogunsipe A., Chen J.-Ya., Nyokong T. New. J. Chem. 2004, 28, $822-827$.

21. Matlaba P., Nyokong T. Polyhedron 2002, 21, 2463-2472.

22. Snow A.W. Phthalocyanine Aggregation. In: The Porphyrin Handbook (Kadish K., Smith K., Guilard R., Eds.). San Diego: Academic Press, 2003, Vol. 17, p. 129-176. 